\title{
A képalkotó vizsgálatok szerepe szívamyloidosis kivizsgálásában
}

\author{
Pozsonyi Zoltán', Peskó Gergely', Czibor Sándor², Dohy Zsófia ${ }^{3}$, \\ Vágó Hajnalka ${ }^{3}$
}

\author{
'Semmelweis Egyetem, Belgyógyászati és Hematológiai Klinika, Budapest \\ ${ }^{2}$ Semmelweis Egyetem, Orvosi Képalkotó Klinika, Nukleáris Medicina Tanszék, Budapest \\ ${ }^{3}$ Semmelweis Egyetem, Városmajori Szív- és Érgyógyászati Klinika, Budapest
}

\author{
Levelezési cím: \\ Dr. Pozsonyi Zoltán PhD; E-mail: pozsonyizoltanimre@gmail.com \\ 1088 Budapest, Szentkirályi utca 46.
}

A szisztémás amyloidosisok szívet érintő formái egyre gyakrabban kerülnek felismerésre. Ennek egyik oka az egyre érzékenyebb képalkotó vizsgálatok széles körű alkalmazása. Másik tényező, hogy szinte az összes forma esetében új, jelentős klinikai haszonnal kecsegtető gyógyszeres kezelési lehetőségek sora jelent meg az elmúlt években. Elsősorban ismeretlen eredetủ balkamra-hipertrófia, megtartott ejekciós frakcióval járó szívelégtelenség, low flow-low grade aortabillentyü-szükület esetén, egyéb meglévő klinikai gyanújelek fennállásakor kell a betegségre gondolni. Ismert szisztémás amyloidosisok esetén is indokolt a sziv érintettségének szürése. A jelenlegi hosszú diagnosztikus késlekedés csökkentésének feltétele, hogy a klinikusok, valamint az echokardiográfiát végzők gondoljanak a betegségre. Fontos a szívamyloidosis diagnosztikájában élvonalbeli szerepet játszó kardiális képalkotó vizsgálatok megfelelő indikációkkal történő elvégzése. Jelen közlemény apropóját a közelmúltban a témával foglalkozó konszenzusdokumentum megjelenése adja. Az összefoglaló didaktikus segítséget próbál adni a szívamyloidosis diagnosztikájához, kiemelve a képalkotó vizsgálatok szerepét.

Kulcsszavak: szívamyloidosis, echokardiográfia, szcintigráfiás vizsgálat, szív-mágnesesrezonancia, képalkotás

\section{Role of imaging modalities in diagnosing cardiac amyloidosis}

Systemic amyloidosis affecting the heart is recognized more often. It is partially because of the extensive use of sensitive imagining studies. On the other hand, in the last couple of years new pharmacological treatment options were developed for nearly all types of cardiac amyloidosis, which promise significant clinical benefit for the patients. The suspicion of cardiac amyloidosis should arise primarily with left ventricular hypertrophy without clear etiology, with heart failure with preserved ejection fraction, with low-flow-low-grade aortic stenosis and with further clinical signs of the disease. When systemic amyloidosis is diagnosed then evaluation for heart involvement should be done. To reduce the long diagnostic delay, clinicians and echocardiografists should keep in mind this possible diagnosis. It is important, that cardiac imaging studies have a key role in the diagnosis of cardiac amyloidosis, and should be performed with clear indications. A consensus document was published recently on the role of imaging modalities in cardiac amyloidosis. Our review helps the reader to be up-to-date with the diagnosis of cardiac amyloidosis, and highlights the importance of imaging studies.

Keywords: cardiac amyloidosis, echocardiography, scintigraphy, cardiac magnetic resonance imaging, imaging 


\section{Bevezetés}

Amyloidosisról a szervezetben jelenlévő kóros, vagy normális felépítésű fehérjék béta-redő szerkezetbe öszszeálló extracelluláris lerakódásáról beszélünk. Ez lehet egy szervre, annak egy részére lokalizált forma, például Alzheimer-betegségben, vagy a szervezet nagy részét érintő, szisztémás forma. A szisztémás amyloidosisok között a három leggyakoribb forma az AL-, a TTR- és az AA-típus. AL-amyloidosisban monoklonális könnyü láncok képezik a lerakódó amiloid alapját, a háttérben csontvelői plazmasejtes betegség áll. TTR-forma esetén a májban termelődő transztiretin fehérje rakódik le. Egyik formájában pontmutáció áll a betegség hátterében, ami 40-60 éves kor között kezdődik, másik formájában ismeretlen okból a vad típusú fehérje rakódik le időskorban. Az AA-amyloidosis krónikus betegséghez társul, a szérumamiloid A-fehérje az amiloid fö alkotóeleme (1). A három fő forma fontosabb tulajdonságait, és a klinikailag fontos szervérintettséget az 1. táblázat foglalja össze. Több, igen ritka szisztémás amyloidosis is létezik, ezek azonban a szívet extrém ritkán érintik, ezekről itt nem esik szó. Szívamyloidosis hátterében mintegy 95-98\%-ban az AL-, mTTR-, wtTTR-forma áll. Közös bennük, hogy a prognózist a szívérintettség jelenléte, illetve annak súlyossága határozza meg. Ezt a kérdést a klinikusok számára kidolgozott prognosztikai rendszerek mind az AL-, mind TTR-formák esetében a szérum NTproBNP-szint meghatározásával közelítik meg $(2,3)$. Legrosszabb prognózisa az AL-formának van, ezt az mTTR-, majd a wtTTR-forma követi (4). Fontos azonban, hogy adatink az elmúlt évtizedek betegeiből származnak, ma pedig az összes formában új, egyre hatékonyabb gyógyszeres kezelési lehetőség áll rendelkezésre (5).

Szívamyloidosis lehetőségére gondolhat elsőként a kardiológus, valamilyen panasz, tünet, kardiális eltérés kapcsán, valamint fény derülhet rá, ha ismert a szisztémás betegség, és a szívérintettség jelenlétét akarjuk vizsgálni. Előbbi ismeretlen eredetü balkamra-hipertrófia, megtartott ejekciós frakcióval járó szívelégtelenség, vagy low flow-low grade aortabillentyű-szükület esetén merülhet fel. Utóbbi kettő esetén a legújabb vizsgálatok szerint akár $15-30 \%$ gyakoriságú is lehet a szívamyloidosis $(6,7)$. Különösen akkor gondoljunk rá, ha kétoldali carpal tunnel szindróma, nem diabéteszes eredetủ nephrosis-szindróma, canalis spinalis stenosis, jelentős halláscsökkenés, hipotóniahajlam, béta-blokkoló, ACE-gátló-intolerancia, perifériás neuropathia, monoclonal gammopathy with unknown significance (MGUS), periorbitális purpura szerepel a beteg anamnézisében, ha az illető idős és férfi (wtTTR), az EKG-n relatív vagy abszolút low voltage látható (8).

A korábban rendkívül ritkának gondolt betegséget egyre gyakrabban ismerjük fel, azonban a diagnózis késése most is nagyon hosszú, gyakran éveket jelent (8). Ez vezetett oda, hogy számos ajánlás, javaslat született a diagnosztikát illetően. A következő három fejezet azt foglalja össze, hogy a szívamyloidosis kórismézésében legfontosabb három kardiológiai képalkotó eljárás mivel tud a diagnózishoz járulni, mi azok elönye, limitációja. Ezt követően mutatjuk be ezeknek a vizsgálatoknak egymáshoz viszonyított helyét, illetve a szívamyloidosis diagnosztikus kritériumrendszerét. Jelen közlemény aktualitását az adja, hogy nyolc európai, illetve USA-beli képalkotással, kardiológiával foglalkozó társaság adott ki nemrég közös ajánlást a szívamyloidosis diagnosztikáját illetően $(9,10)$.

Bár jelen közlemény elsősorban a szívamyloidosis képalkotó vonatkozásaival foglalkozik, egyik célja, hogy ráirányítsuk a betegségre a figyelmet, így növelve a diagnosztikus aktivitást és érzékenységet, amely egyben a jobb terápiás lehetőségek feltétele. Ezért Donnelly ábrájának (11) módosításával egy külön

1. TÁBLÁZAT. A leggyakoribb szisztémás amyloidosisok legfontosabb klinikai jellemzői. Wechalekar és munkatársai adatai alapján (1). A brit National Amyloid Centre 1987 és 2012 között 5100 beteget látott, a százalékos értékek innen származnak

\begin{tabular}{|c|c|c|c|c|c|c|c|c|}
\hline \multirow[b]{2}{*}{$\begin{array}{l}\text { Amyloido- } \\
\text { sis típusa }\end{array}$} & \multirow[b]{2}{*}{$\begin{array}{c}\text { Gyakori- } \\
\text { ság }\end{array}$} & \multirow[b]{2}{*}{$\begin{array}{l}\text { Szerzett/ } \\
\text { örökletes }\end{array}$} & \multirow[b]{2}{*}{$\begin{array}{c}\text { Háttérben } \\
\text { álló } \\
\text { eltérés }\end{array}$} & \multirow[b]{2}{*}{$\begin{array}{l}\text { Amiloi- } \\
\text { dogén } \\
\text { fehérje }\end{array}$} & \multicolumn{4}{|c|}{ Érintett szervek } \\
\hline & & & & & Szív & Vese & $\begin{array}{l}\text { Poly- } \\
\text { neuro- } \\
\text { pátia }\end{array}$ & Egyéb \\
\hline $\mathrm{AL}$ & $68 \%$ & szerzett & $\begin{array}{l}\text { plazma- } \\
\text { sejtes } \\
\text { diszkrázia }\end{array}$ & $\begin{array}{l}\text { immuno- } \\
\text { globulin } \\
\text { könnyülánc }\end{array}$ & +++ & +++ & + & $\begin{array}{l}\text { gasztroin- } \\
\text { tesztinális, } \\
\text { kötőszövet }\end{array}$ \\
\hline AA & $12 \%$ & szerzett & $\begin{array}{c}\text { krónikus } \\
\text { gyulladás } \\
\text { (pl. FPS, } \\
\text { RA) }\end{array}$ & sAA & $+/-$ & +++ & - & $\begin{array}{l}\text { gasztro- } \\
\text { intesztinális }\end{array}$ \\
\hline wtTTR & $3 \%$ & szerzett & - & $\begin{array}{c}\text { vad típusú } \\
\text { TTR }\end{array}$ & +++ & - & - & $\begin{array}{c}\text { carpal } \\
\text { tunnel } \\
\text { szindróma }\end{array}$ \\
\hline mTTR & $7 \%$ & örökletes & $\begin{array}{l}\text { TTR-mu- } \\
\text { táció }\end{array}$ & $\begin{array}{c}\text { mutációs } \\
\text { TTR }\end{array}$ & ++ & - & +++ & - \\
\hline
\end{tabular}

TTR=transtiretin. mTTR: mutációs típusú TTR-amiloid. wtTTR: vad típusú TTR-amiloid. FPS=familiáris láz szindrómák. PNP=perifériás polyneuropathia. $R A=r-$ heumatoid arthritis. SAA=szérum amiloid A. +++ nagyon gyakori, ++ gyakori, + kevésbé gyakori; -/+ ritka; - nem értelmezhető, $A A=a m i l o i d ~ A$ 
2. TÁBLÁZAT. Szívamyloidosis lehetőségére utaló echokardiográfiás és klinikai jelek, a betegség úgynevezett „vörös lobogói”, angolul red flags. A táblázat Donnelly és munkatársainak közleménye alapján (3), annak többszörös módosításával készült

Szívamyloidosis - vörös lobogók

Szívultrahang:

$$
\begin{aligned}
& \text { - ismeretlen eredetű balkamra-hipertrófia } \\
& \text { - vastag kamrafalak és szeptum mellett low voltage az EKG-n } \\
& \text { - a jobb kamra szabad falának és a billentyük megvastagodása } \\
& \text { - low flow-low grade aortabillentyü-szűkület } \\
& \text { - megtartott ejekciós frakcióval járó szívelégtelenség (HFpEF) }
\end{aligned}
$$

Intolerancia béta-blokkolókkal és ACE-gátlókkal szemben

Korábban magas vérnyomás miatt kezelt beteg esetén mért alacsony tenziók

Kétoldali carpal tunnel miatti mütét az anamnézisben

$\mathrm{AL}$

HFpEF és nephrosis-szindróma macroglossia, periorbitális purpura orthosztatikus hipotónia perifériás neuropathia MGUS
ATTR

60 év feletti férfi - HFpEF és carpal tunnel szindróma vagy spinális stenosis hipertrófiás cardiomyopathia mint új diagnózis időskorban low flow low grade aortastenosis, mint új diagnózis időskorban mATTR a családi kórtörténetben

ACE: angiotenzin-konvertáló enzim; AL: immunoglobulin könnyülánc-amyloidosis; ATTR transztiretin-amyloidosis; EKG: elektrokardiogram; ATTRm: az ATTR mutációs, herediter formája; HFpEF: szívelégtelenség megtartott balkamrai ejekciós frakció mellett; MGUS: kérdéses jelentőségű monoklonális gammopathia

táblázatban foglaljuk össze a legfontosabb echokardiográfiás és klinikai helyzeteket (red flags - vörös lobogók), amikor a betegség lehetőségére gondolni kell (2. táblázat).

\section{Az echokardiográfia}

Legfontosabb előnye a könnyű elérhetőség, az ismételhetőség. Részben rutinszerü alkalmazása az oka az egyre gyakrabban megtalált betegségnek, egyben differenciáldiagnosztikai szerepe is van. A szívamyloidosis klasszikus szívultrahangos jeleit érdemes lehet morfológiai és funkcionális csoportba osztani. Az elsőbe az alábbiak tartoznak: $12 \mathrm{~mm}$ falvastagságot meghaladó koncentrikus balkamra-hipertrófia, megvastagodott jobb kamrai szabad fal, tág pitvarok az emelkedő pitvari nyomás miatt, megvastagodott mitralis, tricuspidalis és néha aortabillentyű, megvastagodott pitvari szeptum, perikardiális folyadék, a szívelégtelenség miatt gyakran pleurális folyadék. A funkciót illetően az alábbi jellegzetességeket találjuk: Kezdetben a bal kamrai ejekciós frakció megtartott, azonban a BKH miatti szűkebb üreg miatt a verővolumen korán csökkenni kezd. A kamrai szisztolés funkció azonban már ekkor is csökkent, amit a mitralis és tricuspidalis anulus szisztolés sebességének csökkenése jelez. A globális longitudinális strain (GLS) is csökken. Később a bal kamarai ejekciós frakció is csökken. Másik funkcionális jel a kezdetben enyhébb fokú, majd egyre súlyosabb diasztolés funkciózavar. Jellemző az emelkedett bal pitvari töltőnyomás, amelynek jele a nagy mitralis E-hullám és rövid decelerációs idő mellett a szöveti Dopplerrel mért kicsi mitralis anulus diasztol- és (E') hullám. Általában magas a számított szisztolés pulmonalis nyomás és tág az IVC.

Néhány éve került leírásra egy különleges, igen szenzitív és specifikus jele a szívamyloidosisnak, ez pedig a Iongitudinális strain egyenetlen csökkenése a bal kamrában (12). Oki háttere nem pontosan ismert, de azt látjuk, hogy a bazális és középső harmadi strain csökkenése sokkal kifejezettebb, mint a csúcsi szegmentumoké, úgynevezett apical sparing jelensége látható. A típusos bull's eye képe miatt a cherry on the top (cseresznye a tetején) kifejezéssel is szokás illetni (1. ábra). Számszerüsítéshez a csúcsi szegmentumok strain átlagát osztjuk a középső harmadi szegmentumok strain átlagának és a bazális harmadi strain átlagösszegével (átlag csúcsi LS/[átlag bazális LS + kp harmadi-LS]). Az eredeti közleményben az egynél nagyobb szám 93\% szenzitivitással és $82 \%$ specificitással jelezte az amyloidosist BKH esetén (12).

Az echokardiográfiás vizsgálat során mindig érdemes legalább egy pillantást vetni az EKG-ra, hiszen jelentősebb BKH melletti low voltage a betegségre utal. Az echokardiográfia technikai okokból korlátozottan alkalmas a differenciáldiagnosztikára, ebben az MR jobban teljesít. Azonban így is az esetek jelentős részében egyéb betegségeket tárhat fel. Ezek közül a legfontosabbak: hipertrófiás cardiomyopathia, hipertónia okozta balkamra-hipertrófia, aortabillentyű-stenosis, ritka genetikai betegségek, például Fabry- és Dannon-betegség. Természetesen föleg az utóbbi esetekben a klinikum ismeretének és az MR-vizsgálatnak is nélkülözhetetlen szerepe van.

A szívultrahang-vizsgálat lehetőséget ad a betegség progressziójának követesére vagy, ahogy szerencsére egyre többször látjuk, a betegség klinikai javulásának 


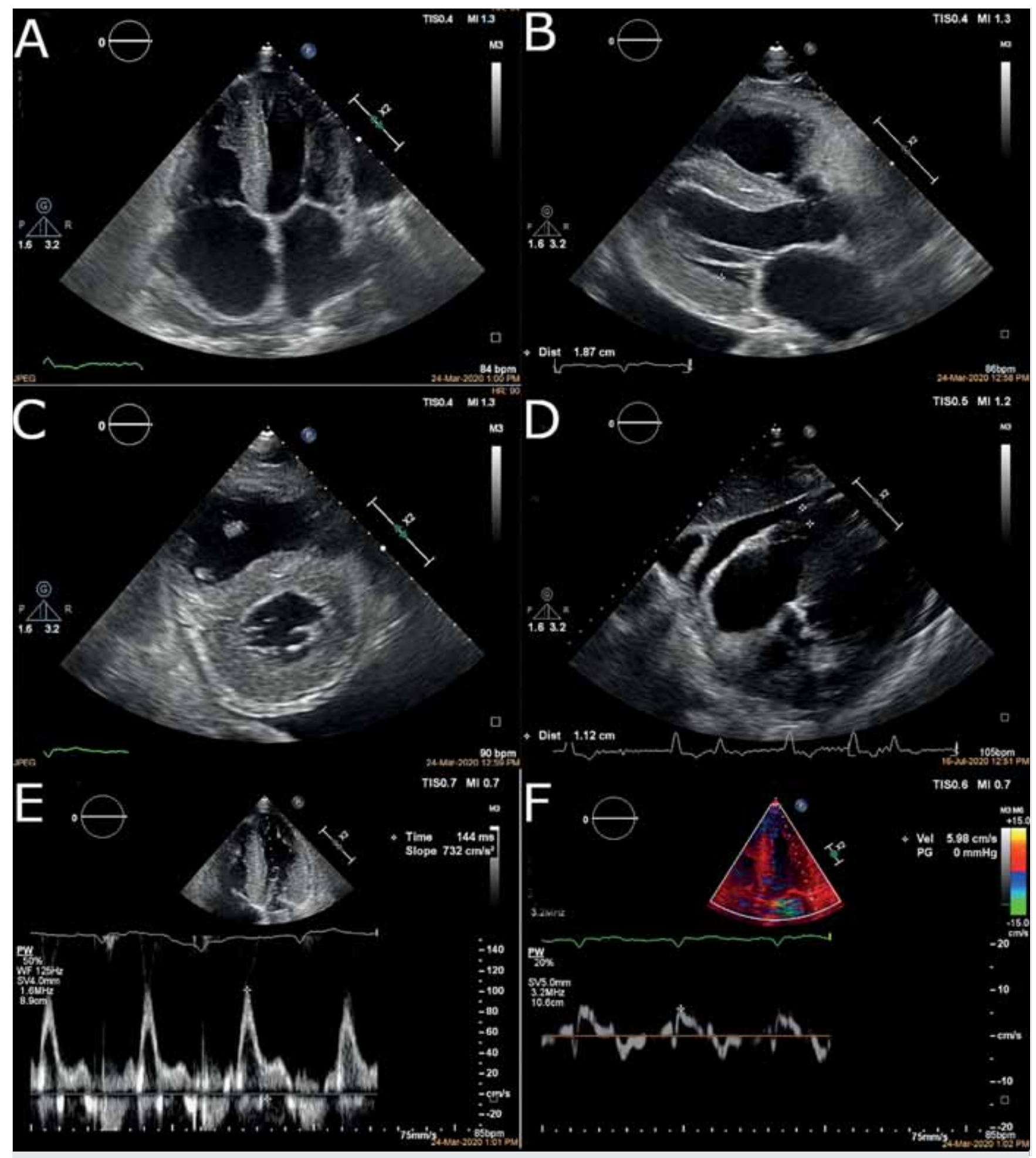

1. ÁBRA. Echokardiográfiás képek, szívamyloidosis (Semmelweis Egyetem, Belgyógyászati és Hematológiai Klinika anyaga)

A: Csúcsi 4 üregű felvétel, amelyen a jelentős balkamra-hipertrófia mellett a tág pitvarok szembeötlőek.

B: Parasternalis hosszmetszeti kép. 19 mm-es kamrafal, vaskos mitralis billentyű. Bal oldali mellkasi folyadék a szív mögött.

C: Parasternalis rövid tengelyi végdiasztolés felvétel. Jelentős koncentrikus balkamra-hipertrófia, kicsi üreg, vastag JK szabad fal.

D: Subcostalis ablakból kevés perikardiális folyadék és $11 \mathrm{~mm}$-es jobb kamrai szabad fal ábrázolódik végdiasztoléban.

E: Sinusritmus mellett magas mitralis beáramlási E- és alacsony A-hullám, rövid DT-idő.

F: A mitralis anulus Doppler-görbéje. A szisztolés és diasztolés hullámok is rendkívül alacsonyak. 


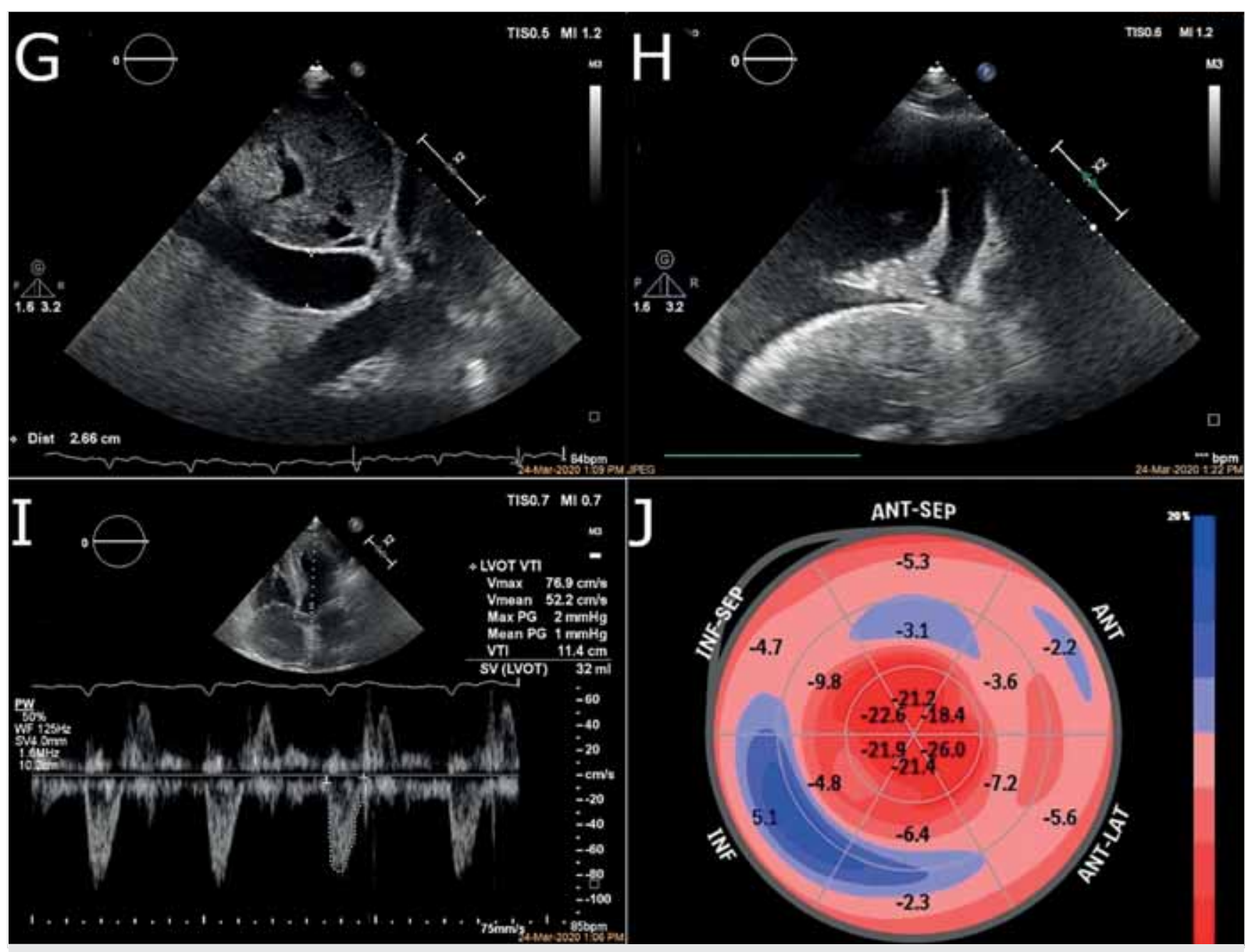

1. ÁBRA. Echokardiográfiás képek, szívamyloidosis (Semmelweis Egyetem, Belgyógyászati és Hematológiai Klinika anyaga) G: Tág IVC, jobbszívfél-elégtelenség jele. H: A mellkas vizsgálata ülve: jobb oldalon jelentős mennyiségű hydrothorax. I: A bal kamrai kiáramlási pálya átmérő mérésének segítségével (nincs az ábrán) a kiáramlási pályában szisztoléban mért pulzatilis Doppler-görbe alapján a verővolumen számolható. a $32 \mathrm{ml}$-es érték igen alacsony. J: Típusos longitudinális endokardiális straineloszlási értékek. A csúcsban normális, máshol jelentősen csökkent. A kép ad értelmet a "cherry on top" elnevezésnek.

dokumentálására. Nemcsak a bal kamra falvastagsága, hanem a diasztolés funkciózavar foka, a perikardiális és pleurális folyadékok ábrázolása is segít a terápia hasznának megítélésében (13).

A szívultrahang fő limitációja, hogy rossz echoablak esetén nehéz a kép értékelése, a bal kamrai strain ábrázolása igen bizonytalan lesz. Nehezíti a helyzetet, hogy szívamyloidosis kezdeti stádiumában a fent leírt echokardiográfiás jelek nem, vagy csak alig mutatkoznak. llyenkor akár még a BKH is hiányozhat, annak ellenére, hogy a biomarkerek már jelzik a szív érintettségét.

\section{A mágnesesrezonancia-vizsgálat}

A szívmágnesesrezonancia (MR)-vizsgálatnak kiemelt szerepe van a kardiális amyloidosis noninvazív diagnosztikájában, köszönhetően annak, hogy az MR a szív pontos morfológiai és funkcionális megítélése mellett szöveti információt is nyújt. Amyloidosissal összefüggésben a szív-MR-vizsgálat indikációja lehet balkamra-hipertrófia esetén az amyloidosis elkülönítése más cardiomyiopathiáktól, valamint ismert szisztémás amyloidosis esetén a szív érintettségének megítélése. A kardiális amyloidosis részletes szív-MR elemzése magában foglalja a bal és jobb kamra, valamint a pitvarok morfológiai és funkcionális megítélését, a késői kontrasztanyag-halmozás értékelését, illetve a natív $T_{1}$ mapping és extracelluláris volumen- (ECV) méréseket (10).

Az amyloidosisra jellemző késői kontrasztanyag-halmozási mintázat a körkörös subendocardialis vagy transzmurális halmozás, amely leginkább a bazális szegmentumokat érinti, és nem követi az egyes koszorúserek ellátási területét. Az esetek egy részében mindkét kamrában és a pitvarokban is kimutatható a 


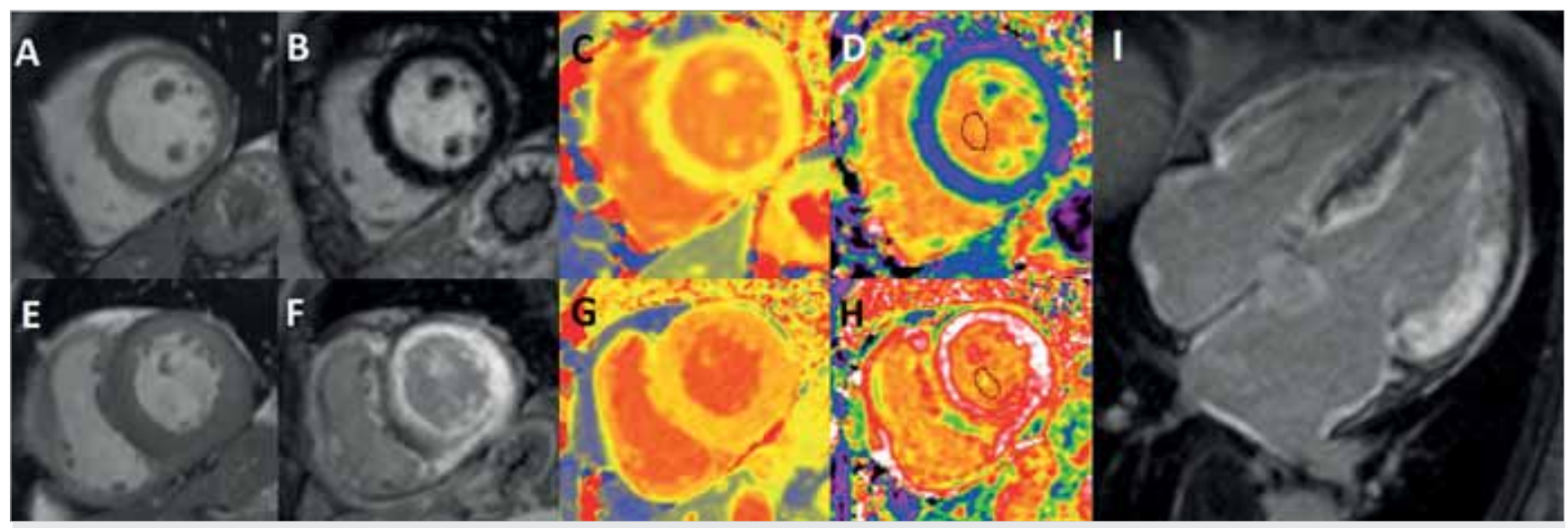

2. ÁBRA. Szív-MR-felvételek (Semmelweis Egyetem, Városmajori Szív- és Érgyógyászati Klinika anyaga) A-D: Normál szív MR képe: A: rövid tengelyi mozgófelvétel végdiasztolés fázisban, a maximális végdiasztolés falvastagság $8 \mathrm{~mm}$; $\mathrm{B}$ : késői kontrasztanyag-halmozásos felvétel, kontrasztanyag-halmozás nem azonosítható; C: natív $\mathrm{T}_{1}$-mapping felvétel, $\mathrm{T}_{1}$-érték $950 \mathrm{~ms}$; D: ECV-mérés, ECV-érték 25\%. E-H: Kardiális amyloidosis szív-MR-képe: E: rövid tengelyi mozgófelvétel végdiasztolés fázisban, koncentrikus balkamra-hipertrófia, a maximális végdiasztolés falvastagság 18 mm; F: késői kontrasztanyag-halmozásos felvétel, diffúz bal és jobb kamrai kontraszthalmozás; G: natív $T_{1}$-mapping felvétel, $T_{1}$-érték $1140 \mathrm{~ms} ; \mathrm{H}$ : ECV-mérés, ECV-érték 77\%. I: Késői kontrasztanyag-halmozásos felvétel 4-üregi nézetben. Amyloidosisra jellemző kontraszthalmozás ábrázolódik a bal és jobb kamrai myocardiumban, valamint a pitvarokban

kontrasztanyag-halmozás (2. ábra) (14-16). Amyloidosisra jellemzö, hogy az MR-vizsgálat során sokszor nehéz a myocardium „kinullázása” a késői kontraszthalmozásos felvételeken (olyan inverziós idő kiválasztása, amivel a normál szívizomszövet alacsony jeladással [feketén] ábrázolódik), illetve hogy a vér és a myocardium együtt „nullázódnak” köszönhetően a megnövekedett miokardiális ECV-nek (17). Különbséget írtak le a kontrasztanyag-halmozás mintázatában az amyloidosis típusától függően, amely szerint a transztiretin típusú amyloidosisban (szenilis szisztémás amyloidosis) gyakoribb a transzmurális kontraszthalmozás összehasonlítva a könnyűlánc-amyloidosissal (18).

$A z$ újabb mapping technikáknak köszönhetően kvantitatív információt is kaphatunk a myocardium szöveti tulajdonságairól $(19,20)$. A natív $T_{1}$-mapping segítségével kontrasztanyag adása nélkül következtethetünk miokardiális fibrózis, illetve amiloidlerakódás jelenlétére. Amyloidosisra jellemző a myocardium jelentősen emelkedett $\mathrm{T}_{1}$-értéke (21). Kontrasztanyag alkalmazásával a natív és kontrasztanyag utáni $T_{1}$-mapping felvétel lehetővé teszi a miokardiális ECV mérését. Amyloidosis esetén emelkedett ECV-értéket mérhetünk akár már a kontrasztanyag-halmozás megjelenése előtt is, így az ECV-emelkedés korai markere lehet az amyloidosis kardiális érintettségének (2. ábra). Mind a natív $T_{1}$, mind az ECV-mérés alkalmas lehet az amiloidlerakódás időbeni változásainak követésére $(22,23)$.

A miokardiális deformáció jellegzetes változásokat mutat amyloidosis esetén, amelynek elemzésére a strainanalízist használhatjuk. A feature tracking technika alkalmas a szív-MR-vizsgálat során készült hagyományos mozgó felvételeken a strain-paraméterek meghatározására. Amyloidosisra jellemzők a csökkent

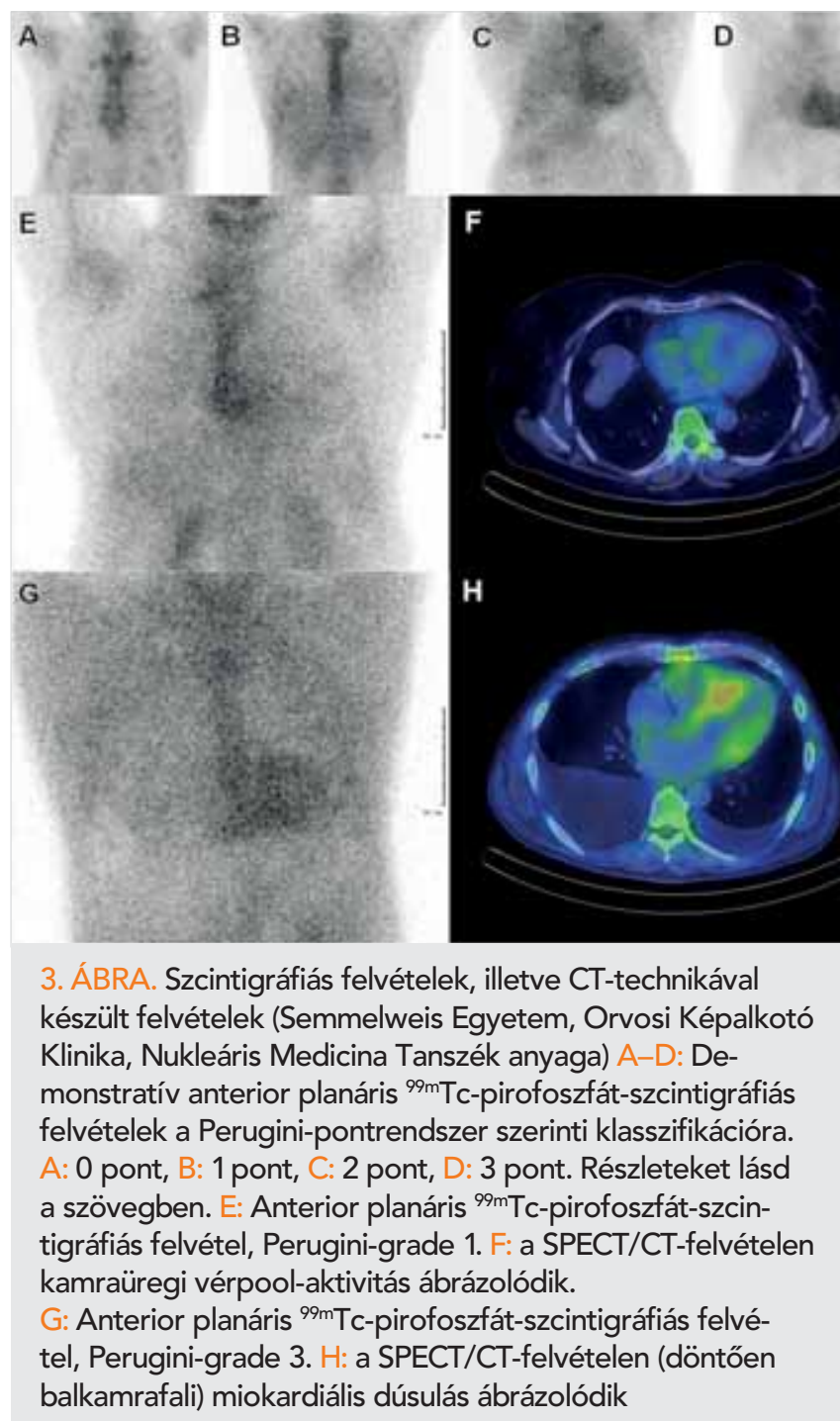


3. TÁBLÁZAT. A szívamyloidosis diagnózisa. Szakértői konszenzusdokumentum $(9,10)$ módosított táblázata

\author{
Diagnosztikai kritériumok
}

Amyloidosis típusa

\title{
Szívamyloidosis szövettani diagnózisa: endomiokardiális biopszia
}

Endomiokardiális biopszia, Kongó-vörös festéssel, amely polarizált fényben vizsgálva almazöld kettős törést mutat. Immunhisztokémiai/tömegsterometriai tipizálás

AL, TTR, AA, egyéb típusok

\section{Szívamyloidosis szövettani diagnózisa: extrakardiális biopszia}

TTR-amiloidot igazoló extrakardiális biopszia és típusos kardiális képalkotó jellemzők (lásd lejjebb)

TTR

AL-amyloidot igazoló extrakardiális biopszia és típusos kardiális képalkotós jellemzők vagy mással nem magyarázható biomarker, NTproBNP/hsTroponin-emelkedés

$\mathrm{AL}$

\section{TTR-szívamyloidosis diagnózisa, ${ }^{99 \mathrm{~m} T C-P Y P, ~ D P D, ~ H M D P-i z o t o ́ p p a l ~}$}

2 vagy 3 pontot érő ${ }^{99 m}$ Tc-PYP, DPD, HMDP-izotóp dúsítás a szívben és klonális plazmasejtes betegség hiánya (normális kappa/lambda arány, negatív immunfixáció) és típusos kardiális képalkotó jellegzetességek

TTR

\section{Szívamyloidosis típusos jellegzetességei kardiális képalkotókkal}

Típusos echokardiográfiás vagy szív-MR jellegzetességek: az alábbi képalkotó jellemzők bármelyike, ha azok egyéb hátterét (pl. hipertónia) ki lehet zárni

Echokardiográfia

- 12 mm-nél vastagabb bal kamrai falvastagság

- Strainanalízis során „apical sparing” (átlag csúcsi LS/(átlag bazális LS + kp harmadi-LS>1

- Grade II vagy súlyosabb diasztolés diszfunkció

Szív MR

- Nemre, életkorra korrigáltnál vastagabb balkamra-fal a mozgó felvételeken

- Extracelluláris volumen>40\%

- Diffúz késői típusú kontrasztanyag-halmozás

TTR/AL

- Amyloidosisra típusos gadolínium kinetika, a szívizom korábban átmegy a „nullponton” mint a vér (lásd szöveg)

globális strain-paraméterek, illetve a bázis felé egyre csökkenő longitudinális strainérték $(24,25)$, az a kép, amit az szívultrahangos leíráshoz hasonlóan „apical sparingnek" nevez az irodalom (12).

Az amyloidosis prognózisát jelentősen meghatározza a szivérintettség jelenléte. Magasabb halálozás tapasztalható azoknál az amyloidosisos betegeknél, akiknél szív MR-vizsgálat során kontraszthalmozás mutatható ki (26). Az emelkedett natív $T_{1}$-mapping-érték és az emelkedett ECV ugyancsak segíthetnek a betegek prognózisának meghatározásában $(27,28)$.

A szív-MR-vizsgálat limitációját, abszolút, vagy relatív ellenjavallatát, a felvételek nehezített értékelhetőségét képezi a vizsgálat korlátozott elérhetősége, a klausztrofóbia, a ritmuszavarok, elsősorban a pitvarfibrilláció fennállása, a korábban implantált pacemakerek és ICD-k, a súlyos veseelégtelenség, az orthopnoe, illetve a beteg kooperációjának hiánya.

\section{Szcintigráfiás módszerek}

Több mint négy évtizede ismert, hogy ${ }^{99 m} T c$-izotóppal jelölt difoszfonát-származékok és pirofoszfát fokozott dúsulást mutatnak szívamyloidosisban szenvedő betegek myocardiumában (29). A huszonegyedik században a jelenség intenzívebb kutatása során bizonyítást nyert, hogy a szívamyloidosist leggyakrabban okozó transztiretin- és könnyülánc-típusú amyloidosis közül előbbiben jóval intenzívebb a miokardiális pirofoszfát/ difoszfonát-dúsulás, bár a kötődési mechanizmus máig ismeretlen (hátterében a mikrokalcifikációk jelenlétét feltételezik) $(30,31)$. A szcintigráfiás vizsgálatok vizuális értékelésére szolgáló hatékony és nagyszámú betegen vizsgált módszer a négyfokú Perugini-pontrendszer (32), amely az alábbiak szerint írja le a dúsulás fokozatait a szívben (3. ábra):

- 0 pont: nincs dúsulás a myocardium vetületében.

- 1 pont: diszkrét dúsulás a myocardium vetületében, amely intenzitása nem haladja meg a környező csontokét.

- 2 pont: a környező csontok felvételével megegyező intenzitású miokardiális dúsulás.

- 3 pont: a környező csontok felvételénél jóval intenzívebb miokardiális dúsulás.

A szcintigráfiás módszer kiváló diagnosztikus teljesítményét támasztotta alá egy 2016-ban publikált multicentrikus kutatás, amelynek során 374 esetben állt rendelkezésre endomiokardiális biopszia szövettani eredménye, illetve pirofoszfát/difoszfonát szcintigram - utóbbin Perugini-grade 2-3 értékeket pozitívnak tekintve az izotópvizsgálat szenzitivitása 91\%-nak, specificitása $87 \%$-nak adódott transztiretin-szívamyloidosis noninvazív kimutatására (33). Amikor a szérum és vizelet könnyülánc szintjének, valamint immunfixációs vizsgálatával kizárták a monoklonális protein jelenlétét, a vizuális szemikvantitatív 2-3 pontnak transztiretin amyloidosis irányában a specificitása és pozitív predik- 
tív értéke $100 \%$ volt, $74 \%$-os szenzitivitás mellett (33). A szcintigráfiás vizsgálat robosztus és pontos voltát megerősítette egy, összesen 529 beteg publikált adatait feldolgozó metaanalízis is, amelynek során a Perugini-grade 2-3 szcintigramok szenzitivitása 92,2\%-nak, specificitása 95,4\%-nak bizonyult transztiretin-szívamyloidosis kimutatásában (34). Fenti eredményeket is figyelembe véve, a közelmúltban kiadott, feljebb már hivatkozott számos nemzetközi kardiológiai és képalkotó társaság által jegyzett ajánlás alapján invazív endomiokardiális biopszia elvégzése nélkül is igazoltnak tekintendő a transztiretin-szívamyloidosis jelenléte, amennyiben Perugini-grade 2-3 fokú halmozás ábrázolódik a pirofoszfát/difoszfonát szcintigráfián és monoklonális protein jelenléte laboratóriumi vizsgálattal kizárható $(9,10)$.

Ezen ajánlásban foglalt megfelelő használati kritériumok alapján igazolt TTR-génmutációt hordozó egyénekben kardiális tünetek hiányában is javasolt a szcintigráfia időszakos elvégzése. Szintén szürő jelleggel, új keletủ szívelégtelenség bizonyos eseteiben (kiemelvén a más etiológiával nem magyarázható balkamrafal-vastagodást, az alacsony áramlású és -grádiensű aortastenosist és a kapcsolódó, ismeretlen etiológiájú perifériás szenzorimotoros neuropathiát) is javasolt szcintigráfiás vizsgálat, transztiretin szívamyloidosis kizárására $(9,10)$.

Megjegyzendő, hogy rutin (onkológiai vagy ortopédiai/ reumatológiai indikációval végzett) csontszcintigráfiák során is észlelhetünk ritkán miokardiális foszfonátdúsulást szívamyloidosis hiányában is. Ennek hátterében számos, döntően gyulladásos folyamat állhat, illetve malignus és metabolikus kórképek kísérőjelenségeként is felléphetnek (35). Egy átfogó, retrospektív tanulmány során 12400 csontszcintigráfia utólagos elemzése során 45 esetben $(0,36 \%)$ ábrázolódott miokardiális halmozás, amely közel harmadában, tizennégy betegnél szívamyloidosis igazolódott (36). Ugyanakkor, egy másik, közel hétezer csontszintigráfiát elemző tanulmány eredményei alapján a 85 évesnél idősebb férfiak 6,15\%ában ábrázolódott miokardiális foszfonát-akkumuláció, és mindegyik beteg echokardiográfiás vizsgálata szívamyloidosisra típusos eltéréseket mutatott (37).

A szcintigráfiás technológia gyakorlati megfontolásai közül fontos kiemelni a SPECT (és lehetőség szerint SPECT/CT) fontosságát, mivel ezen háromdimenziós nukleáris képalkotó módszer elősegíti a tényleges miokardiális dúsulás és a szívüregi vérpool-aktivitás differenciálását, növelve a diagnosztikus pontosságot a planáris felvételekhez képest (3. ábra) (38). A hazai izotópdiagnosztikai gyakorlatban széles körben elérhető difoszfonátok, a metilén-difoszfonát (MDP) és hidroxi-metilén-difoszfonát (HDP) közül az MDP használata kerülendő, mivel az egyéb farmakonokhoz mérhető fokú miokardiális dúsulása vitatott szívamyloidosisban (32). Összességében, a szívamyloidosis kivizsgálásában kardinális szerepet betöltő szcintigráfiás módszer rutin klinikai diagnosztikában való alkalmazhatóságát ${ }^{99 \mathrm{~m} T c-p i r o f o s z f a ́ t ~ e ́ s ~ a ~}{ }^{99 \mathrm{~m} T c-H D P}$ ), illetve a magyarországi nukleáris medicina osztályokon a szükséges instrumentáció is rendelkezésre áll. A vizsgálat nem drága, ritmuszavarok, veseelégtelenség, implantált pacemakerek esetén is elvégezhető. A vizsgálat limitációját képezheti a sugárterhelés, amelynek mértéke azonban relatíve alacsony, valamint szükség van az értékeléshez bizonyos fokú tapasztalatra is.

\section{A szívamyloidosis diagnosztikus kritériumrendszere: a képalkotók helye}

Az előző fejezetekben már idézett, két részben megjelent közleményben nyolc kardiológiai, illetve képalkotással foglalkozó szakmai társaság tett a közelmúltban javaslatot, hogyan lehet elfogadni a szívamyloidosis diagnózisát $(9,10)$. Ezt az érthetőség és átláthatóság kedvéért az eredeti közlemény alapján mi is táblázat formájában (3. táblázat) foglaltuk össze. Bár a táblázatban nem szerepel, szerzők közös véleménye, hogy a diagnózishoz vezető út legfontosabb lépése, hogy gondolni kell a betegségre. Ha ez megtörténik, innentöl kezdve elöbb-utóbb diagnózis születik. A saját betegeink között tapasztalt, és az irodalomban is leírt hosszú diagnosztikus késés nem a képalkotó vizsgálatok elérhetetlenségéből, hanem a klinikai gyanú hiányából adódik. Gyakori, hogy az echokardiográfia során az észlelt balkamra-hipertrófia ellenére nem merül fel a klinikai gyanú, és nem készül strainanalízis, vagy pirofoszfát/ difoszfonát izotóp-, szív-MR- és az ilyenkor szükséges laboratóriumi vizsgálat.

A táblázatból két klinikai helyzetet emelnénk ki, amely mindenképpen figyelmet érdemel az újszerü megközelítés miatt. Az egyik az, hogy ma már rutinszerü lehetőség van a TTR-szívamyloidosis igazolására biopszia végzése nélkül is. Ha 2-3 pontot ad a pirofoszfát/difoszfonát izotóp, és laborvizsgálattal kizárható a monokIonális plazmasejtes betegség jelenléte (szérum kappa- és lambda-könnyűlánc és immunofixáció végzése, vizeletből immunofixáció végzése), igazoltnak kell tekinteni a TTR-szívamyloidosist. llyenkor a TTR-gén vizsgálata a következő lépés a vad- és mutációs típus elkülönítésére. Ez a megközelítés egyszerüségében újszerü, és lehetőséget ad az idősebb, megtartott ejekciós frakciójú szívelégtelen betegek szinte szürőjellegü vizsgálatára. Első szerző szóbeli közlés alapján úgy tudja, több nyugat-európai izotóplaborban ma már ez a vizsgálat teszi ki az összes izotópvizsgálat többségét. A másik, újszerű klinikai helyzet a konszenzusdokumentum alapján az, amikor az AL-típusú szívamyloidosis diagnózisát úgy fogadjuk el, hogy a képalkotó vizsgálatok egyike sem utal egyértelmüen a betegségre, de igazolt a monoklonális könnyü láncok jelenléte a vérben, típusos, de nem szívből származó szövettani lelet áll rendelkezésre, és a BNP, troponinszint mással meg nem magya- 
rázható okból emelkedést mutat. llyenkor egy esetlegesen elvégzett szívizom-biopszia pozitív lenne. Ez a fajta klinikai szcenárió nem is annyira ritka, saját tapasztalat szerint az AL-típusú szisztémás amyloidosisos betegek akár $10 \%$-át is érintheti. Ez a fajta klinikai helyzet azonban felhívja arra a figyelmet, hogy az echokardiográfia és a szív-MR szenzitivitása nem éri el a 100\%-ot, főleg a kezdeti stádiumban lévő betegeket lehet „elnézni”, holott pont ezeknek a betegeknek a korán elkezdett kezelésétől várható a legtöbb klinikai haszon.

A táblázatban nem szerepel, mi a teendő, ha 2-3 pontot adó pirofoszfát/difoszfonát izotópos vizsgálat mellett monoklonális könnyűlánc mutatható ki a vérből. Ilyenkor, csakúgy, mint az 1 pontot adó izotópvizsgálat után, további, elsősorban szövettani vizsgálatra van szükség. Gyakran a hasfali zsírból, gingivából, rectumból vett szövettan nem diagnosztikus, az előny-kockázat mérlegelése után érdemes lehet már elsőként az endomiokardiális biopsziát elvégezni.

\section{Szívamyloidosisos beteg követése, a képalkotók helye}

Mivel az elmúlt években mind a z AL-, mind a TTR-amyloidosisban egészen új kezelési lehetőségek merültek fel, igény keletkezett arra is, hogy a követés, a betegség lefolyásának, javulásának, progressziójának megítélését is objektív alapokra helyezzük. A gyakran rendkívül drága terápiák sikerét lehet így mérni, illetve sikertelenség esetén ezek között váltani, vagy felhagyni alkalmazásukkal, esetleg a szívtranszplantáció lehetőségét keresni. TTR esetén a közelmúltban jelent meg erre vonatkozó ajánlás (13), amely számos klinikai és laborparaméter (például: EKG, Holter, BNP, troponin, szérum-összfehérje, albuminvizsgálat, testsúlymérés, neuropathiás vizsgálatok, 6 perces járásteszt, ergospirometria, egyes esetekben a szérum TTR-szint mérése) 3-6 havonta történő ellenőrzése mellett az echokardiográfiának ad szerepet, azonban az értékelést komplex módon, az összes rendelkezésre álló információ alapján javasolja végezni. AL esetén a kezelést vezérlő legfontosabb paraméter a szérum monoklonális könnyűlánc szintjének mérése. A betegség stabilizálására, esetleg javulására ennek jelentős csökkenése esetén van reális esély. A fent részletezett paraméterek rendszeres vizsgálata mellett itt is az echokardiográfiának jut szerep, bár gyakran látjuk, hogy semmiféle, vagy minimális echos változások mellet a klinikumban és biomarkerek szintjében szignifikáns romlás/javulás következik be (39).

\section{Következtetések}

Összességében elmondható, hogy a szívamyloidosisnak nemcsak a kezelése, de a diagnosztikája is inter- diszciplináris feladat, amelynek nagy része hárul a kardiális képalkotással foglalkozó kollégákra. Az időben történő felismerés minden forma esetén új terápiás lehetősségek, javuló életkilátások és életminőség lehetőségével kecsegtet. Kiemelendő az elsőként végzett szívultrahang fontossága, hiszen ha itt felmerül a betegség lehetősége, a páciens a további diagnosztikai vizsgálatokra időben kerülhet el.

\section{Nyilatkozat}

Szerzők a folyóirat szerzői útmutatóját elolvasták, beküldés előtt mindnyájan elolvasták a kéziratot, ami máshol nem jelent meg. A cikk megírásáért anyagi juttatásban egyikük sem részesült. A közleménnyel kapcsolatos érdekeltségei, illetve érdekellentétei a szerzőknek nincsenek.

Vágó Hajnalka és Dohy Zsófia munkáját az Innovációs és Technológiai Minisztérium Tématerületi Kiválósági Programja (2020-4.1.1.-TKP2020) finanszírozta, a Semmelweis Egyetem Terápiás Fejlesztés és Bioimaging tématerületi programjai keretében, valamint az Innovációs és Technológiai Minisztérium és a Nemzeti Kutatási, Fejlesztési és Innovációs Hivatal támogatta a Mesterséges Intelligencia Nemzeti Laboratórium keretében.

\section{Irodalom}

1. Wechalekar AD, Gillmore JD, Hawkins PN. Systemic amyloidosis Lancet 2016; 387(10038): 2641-54.

https://doi.org/10.1016/S0140-6736(15)01274-X

2. Gillmore JD, Damy T, Fontana M, Hutchinson M, Lachmann $\mathrm{HJ}$ Martinez-Naharro A, et al. A new staging system for cardiac transthyretin amyloidosis. Eur Heart J 2018; 39(30): 2799-806.

https://doi.org/10.1093/eurheartj/ehx589

3. Kumar S, Dispenzieri A, Lacy MQ, Hayman SR, Buadi FK, Colby $C$, et al. Revised prognostic staging system for light chain amyloidosis incorporating cardiac biomarkers and serum free light chain measurements. J Clin Oncol 2012; 30(9): 989-95.

https://doi.org/10.1200/JCO.2011.38.5724

4. Kocher F, Kaser A, Escher F, Doerler J, Zaruba MM, Messner M et al. Heart failure from ATTRwt amyloid cardiomyopathy is associated with poor prognosis. ESC Heart Fail. 2020.

https://doi.org/10.1002/ehf2.12986

5. Gertz MA, Dispenzieri A. Systemic Amyloidosis Recognition, Prognosis, and Therapy: A Systematic Review. JAMA 2020; 324(1): 79-89. https://doi.org/10.1001/jama.2020.5493

6. Ternacle J, Krapf L, Mohty D, Magne J, Nguyen A, Galat A, et al. Aortic Stenosis and Cardiac Amyloidosis: JACC Review Topic of the Week. J Am Coll Cardiol 2019; 74(21): 2638-51.

https://doi.org/10.1016/j.jacc.2019.09.056

7. Russo D, Musumeci MB, Volpe M. The neglected issue of cardiac amyloidosis in trials on heart failure with preserved ejection fraction in the elderly. Eur J Heart Fail 2020; 22(9): 1740-1.

https://doi.org/10.1002/ejhf.1766

8. Gertz M, Adams D, Ando Y, Beirao JM, Bokhari S, Coelho T, et al. Avoiding misdiagnosis: expert consensus recommendations for the suspicion and diagnosis of transthyretin amyloidosis for the general practitioner. BMC Fam Pract 2020; 21(1): 198.

https://doi.org/10.1186/s12875-020-01252-4

9. Dorbala S, Ando Y, Bokhari S, Dispenzieri A, Falk RH, Ferrari VA, et al. ASNC/AHA/ASE/EANM/HFSA/ISA/SCMR/SNMMI expert consensus recommendations for multimodality imaging in cardiac 
amyloidosis: Part 1 of 2-evidence base and standardized methods of imaging. J Nucl Cardiol 2019; 26(6): 2065-123. https://doi.org/10.1007/s12350-019-01760-6

10. Dorbala S, Ando Y, Bokhari S, Dispenzieri A, Falk RH, Ferrari VA, et al. ASNC/AHA/ASE/EANM/HFSA/ISA/SCMR/SNMMI expert consensus recommendations for multimodality imaging in cardiac amyloidosis: Part 2 of 2-Diagnostic criteria and appropriate utilization. J Nucl Cardiol 2020; 27(2): 659-73. https://doi.org/10.1007/s12350-019-01761-5

11. Donnelly JP, Hanna M. Cardiac amyloidosis: An update on diagnosis and treatment. Cleve Clin J Med 2017; 84(12 Suppl 3): 12-26. https://doi.org/10.3949/ccjm.84.s3.02

12. Phelan D, Collier P, Thavendiranathan P, Popovic ZB, Hanna M, Plana JC, et al. Relative apical sparing of longitudinal strain using two-dimensional speckle-tracking echocardiography is both sensitive and specific for the diagnosis of cardiac amyloidosis. Heart 2012; 98(19): 1442-8. https://doi.org/10.1136/heartjnl-2012-302353 13. Conceicao I, Coelho T, Rapezzi C, Parman Y, Obici L, Galan L, et al. Assessment of patients with hereditary transthyretin amyloidosis - understanding the impact of management and disease progression. Amyloid 2019; 26(3): 103-11.

https://doi.org/10.1080/13506129.2019.1627312

14. Maceira AM, Joshi J, Prasad SK, Moon JC, Perugini E, Harding I, et al. Cardiovascular magnetic resonance in cardiac amyloidosis. Circulation 2005; 111(2): 186-93.

https://doi.org/10.1161/01.CIR.0000152819.97857.9D

15. Syed IS, Glockner JF, Feng D, Araoz PA, Martinez MW, Edwards $\mathrm{WD}$, et al. Role of cardiac magnetic resonance imaging in the detection of cardiac amyloidosis. JACC Cardiovasc Imaging 2010; 3(2): 155-64. https://doi.org/10.1016/j.jcmg.2009.09.023

16. Vogelsberg H, Mahrholdt H, Deluigi CC, Yilmaz A, Kispert EM, Greulich S, et al. Cardiovascular magnetic resonance in clinically suspected cardiac amyloidosis: noninvasive imaging compared to endomyocardial biopsy. J Am Coll Cardiol 2008; 51(10): 1022-30.

https://doi.org/10.1016/j.jacc.2007.10.049

17. Pandey $T$, Jambhekar K, Shaikh R, Lensing S, Viswamitra S. Utility of the inversion scout sequence (TI scout) in diagnosing myocardial amyloid infiltration. Int J Cardiovasc Imaging 2013; 29(1): 103-12. https://doi.org/10.1007/s10554-012-0042-4

18. Dungu JN, Valencia O, Pinney JH, Gibbs SD, Rowczenio D, Gilbertson JA, et al. CMR-based differentiation of AL and ATTR cardiac amyloidosis. JACC Cardiovasc Imaging 2014; 7(2): 133-42.

https://doi.org/10.1016/j.jcmg.2013.08.015

19. Hirschberg K DZ, Tóth A, Szabó L, Czimbalmos C, Finster M, et al. A mappingtechnikák által nyújtott lehetőségek a szív-MR-vizsgálatok során: indikációk, diagnosztikus érték, limitációk és centrumunk kezdeti tapasztalatai. Cardiologia Hungarica 2020; 50(1): 4553. https://doi.org/10.26430/CHUNGARICA.2020.50.1.45

20. Messroghli DR, Moon JC, Ferreira VM, Grosse-Wortmann L, $\mathrm{He} \mathrm{T}$, Kellman P, et al. Clinical recommendations for cardiovascular magnetic resonance mapping of $\mathrm{T} 1, \mathrm{~T} 2, \mathrm{~T} 2^{*}$ and extracellular volume: A consensus statement by the Society for Cardiovascular Magnetic Resonance (SCMR) endorsed by the European Association for Cardiovascular Imaging (EACVI). J Cardiovasc Magn Reson 2017; 19(1): 75. https://doi.org/10.1186/s12968-017-0389-8

21. Karamitsos TD, Piechnik SK, Banypersad SM, Fontana M, Ntusi NB, Ferreira VM, et al. Noncontrast T1 mapping for the diagnosis of cardiac amyloidosis. JACC Cardiovasc Imaging 2013; 6(4): 488-97. https://doi.org/10.1016/j.jcmg.2012.11.013

22. Martinez-Naharro A, Abdel-Gadir A, Treibel TA, Zumbo G, Knight DS, Rosmini S, et al. CMR-Verified Regression of Cardiac AL Amyloid After Chemotherapy. JACC Cardiovasc Imaging 2018; 11(1): 152-4. https://doi.org/10.1016/j.jcmg.2017.02.012

23. Martinez-Naharro A, Kotecha T, Norrington K, Boldrini M, Rezk T, Quarta C, et al. Native T1 and Extracellular Volume in Transthyretin Amyloidosis. JACC Cardiovasc Imaging 2019; 12(5): 810-9. https://doi.org/10.1016/j.jcmg.2018.02.006

24. Li R, Yang ZG, Xu HY, Shi K, Liu X, Diao KY, et al. Myocardial
Deformation in Cardiac Amyloid Light-chain Amyloidosis: Assessed with 3T Cardiovascular Magnetic Resonance Feature Tracking. Sci Rep 2017; 7(1): 3794. https://doi.org/10.1038/s41598-017-03699-5 25. Williams LK, Forero JF, Popovic ZB, Phelan D, Delgado D, Rakowski $\mathrm{H}$, et al. Patterns of CMR measured longitudinal strain and its association with late gadolinium enhancement in patients with cardiac amyloidosis and its mimics. J Cardiovasc Magn Reson 2017; 19(1): 61. https://doi.org/10.1186/s12968-017-0376-0

26. Raina $S$, Lensing SY, Nairooz RS, Pothineni NV, Hakeem A, Bhatti S, et al. Prognostic Value of Late Gadolinium Enhancement CMR in Systemic Amyloidosis. JACC Cardiovasc Imaging 2016; 9(11): 1267-77. https://doi.org/10.1016/j.jcmg.2016.01.036

27. Banypersad SM, Fontana M, Maestrini V, Sado DM, Captur G, Petrie A, et al. T1 mapping and survival in systemic light-chain amyloidosis. Eur Heart J 2015; 36(4): 244-51.

https://doi.org/10.1093/eurheartj/ehu444

28. Martinez-Naharro A, Treibel TA, Abdel-Gadir A, Bulluck H, Zumbo G, Knight DS, et al. Magnetic Resonance in Transthyretin Cardiac Amyloidosis. J Am Coll Cardiol 2017; 70(4): 466-77. https://doi.org/10.1016/j.jacc.2017.05.053

29. VanAntwerp JD, O'Mara RE, Pitt MJ, Walsh S. Technetium-99mdiphosphonate accumulation in amyloid. J Nucl Med 1975; 16(3): 238-40.

30. Bokhari S, Castaño A, Pozniakoff T, Deslisle S, Latif F, Maurer MS. (99m)Tc-pyrophosphate scintigraphy for differentiating lightchain cardiac amyloidosis from the transthyretin-related familial and senile cardiac amyloidoses. Circ Cardiovasc Imaging 2013; 6(2): 195-201. https://doi.org/10.1161/CIRCIMAGING.112.000132

31. Rapezzi C, Quarta CC, Guidalotti PL, Pettinato C, Fanti S, Leone $\mathrm{O}$, et al. Role of (99m)Tc-DPD scintigraphy in diagnosis and prognosis of hereditary transthyretin-related cardiac amyloidosis. JACC Cardiovasc Imaging 2011; 4(6): 659-70.

https://doi.org/10.1016/j.jcmg.2011.03.016

32. Perugini E, Guidalotti PL, Salvi F, Cooke RM, Pettinato C, Riva $\mathrm{L}$, et al. Noninvasive etiologic diagnosis of cardiac amyloidosis using 99mTc-3,3-diphosphono-1,2-propanodicarboxylic acid scintigraphy. J Am Coll Cardiol 2005; 46(6): 1076-84 https://doi.org/10.1016/j.jacc.2005.05.073

33. Gillmore JD, Maurer MS, Falk RH, Merlini G, Damy T, Dispenzieri A, et al. Nonbiopsy Diagnosis of Cardiac Transthyretin Amyloidosis. Circulation 2016; 133(24): 2404-12.

https://doi.org/10.1161/CIRCULATIONAHA.116.021612

34. Treglia G, Glaudemans AWJM, Bertagna F, Hazenberg BPC, Erba PA, Giubbini R, et al. Diagnostic accuracy of bone scintigraphy in the assessment of cardiac transthyretin-related amyloidosis: a bivariate meta-analysis. Eur J Nucl Med Mol Imaging 2018; 45(11): 1945-55. https://doi.org/10.1007/s00259-018-4013-4

35. Caobelli F, Paghera B, Pizzocaro C, Guerra UP. Extraosseous myocardial uptake incidentally detected during bone scan: report of three cases and a systematic literature review of extraosseous uptake. Nucl Med Rev Cent East Eur 2013; 16(2): 82-7.

36. Longhi S, Guidalotti PL, Quarta CC, Gagliardi C, Milandri A, Lorenzini $\mathrm{M}$, et al. Identification of TTR-related subclinical amyloidosis with 99mTc-DPD scintigraphy. JACC Cardiovasc Imaging 2014; 7(5): 531-2. https://doi.org/10.1016/j.jcmg.2014.03.004

37. Cuscaden C, Ramsay SC, Prasad S, Goodwin B, Smith J. Estimation of prevalence of transthyretin (ATTR) cardiac amyloidosis in an Australian subpopulation using bone scans with echocardiography and clinical correlation. J Nucl Cardiol 2020.

https://doi.org/10.1007/s12350-020-02152-x

38. Hanna M, Ruberg FL, Maurer MS, Dispenzieri A, Dorbala S, Falk RH, et al. Cardiac Scintigraphy With Technetium-99m-Labeled Bone-Seeking Tracers for Suspected Amyloidosis: JACC Review Topic of the Week. J Am Coll Cardiol. 2020; 75(22): 2851-62. https://doi.org/10.1016/j.jacc.2020.04.022

39. Castiglione V, Franzini M, Aimo A, Carecci A, Lombardi CM, Passino $C$, et al. Use of Biomarkers to Diagnose and Manage Cardiac Amyloidosis. Eur J Heart Fail 2021 